\title{
NETWORKING OPERATING SYSTEM (NOS) BERBASIS SIMULASI MULTIMEDIA
}

\author{
Tri Listyorini \\ Fakultas Teknik, Program Studi Teknik Informatika \\ Universitas Muria Kudus \\ Email: trilistyorini@umk.ac.id \\ Rizkysari Meimaharani \\ Fakultas Teknik, Program Studi Teknik Informatika \\ Universitas Muria Kudus \\ Email: risky.sari@umk.ac.id
}

\begin{abstract}
ABSTRAK
Networking merupakan ilmu yang perkembangannya sangat pesat sekali. Dalam mempelajari sistem operasi jarang sekali mempelajari sistem operasi jaringan. Sebuah Sistem Operasi yang mengkoordinasikan dan mengelola kegiatan dari beberapa komputer dalam sebuah jaringan, itulah yang dinamakan Networking Operating System (NOS). Tujuan dari penelitian ini adalah bagaimana menyampaikan informasi kepada masyarakat tentang Networking Operating System lebih menarik dan mudah dipahami. Dengan metode prototype informasi tersebut dikemas dalam simulasi yang di padukan dengan unsur multimedia. Hasil dari penelitian ini adalah sebuah simulasi berbasis multimedia tentang Networking Operating System (NOS).
\end{abstract}

Kata kunci: networking operating system, prototype, multimedia.

\begin{abstract}
Networking is a science that very rapid development. In studying the operating system rarely learn the network operating system. An Operating System that coordinates and manages the activities of multiple computers in a network, thats called a Networking Operating System (NOS). The purpose of this research is how to convey information to the community what is Networking Operating System more interesting and easy to understand. With prototype method the information is packed in simulation which mix with multimedia element. The result of this research is a multimedia-based simulation of Networking Operating System (NOS).
\end{abstract}

Keywords: networking operating system, prototype, multimedia.

\section{PENDAHULUAN}

Sistem operasi jaringan merupakan sebuah sistem operasi yang dapat membantu masalah jaringan. Pada teorinya sistem operasi jaringan ini dibagi menjadi berbagai layanan/service yang berfungsi untuk melayani user. Layanan tersebut antara lain berbagi berkas, pelayanan untuk penggunaan printer yang dipakai secara bersama, servis DNS, servis http, serta layanan lainnya. Istilah sistem operasi jaringan ini mulai dikenal pada dekade tahun 1980 sampai 1990.

Berkembangnya jaringan yang ada di Indonesia, menuntut untuk mengetahui tentang bagaimana manajemen jaringan tersebut, system operasi jaringan yang dibangun. Menurut Tribun batam menyatakan bahwa pengguna internet di negara pada tahun 2015 mencapai 88,1 juta atau 34,9\% dari keseluruhan 252,4 juta warga Indonesia [1]. Sebagai masyarakat Indonesia tidak hanya menjadi pengguna jaringan tersebut saja, namun harus mengetahui bagaimana jaringan tersebut bisa berkembang lebih maju lagi. Banyak dari masyarakat Indonesia bersifat konsumtif dan ketergantungan dengan jaringan. Karena jaringan telah menjadi kebutuhan yang sangat penting sekarang ini. Namun tidak diimbangi dengan kemampuan masyarakat untuk mengembangkan dan melakukan setting jaringan itu sendiri dan lebih bersifat menggunakan pelayanan dari berbagai teknisi yang ada.

Dari masalah tersebut maka penelitian ini mengambil dasar dari pengaturan sistem operasi jaringan itu sendiri. Karena dengan sistem operasi jaringan merupakan wadah pengendali sumber daya jaringan, menyediakan akses jaringan yang aman, serta sebagai pengatur pemakai agar dapat terkoneksi dengan jaringan tersebut. Oleh karena itu penulis mengambil penelitian tentang pembuatan simulasi berbasis multimedia tentang pembelajaran sistem operasi jaringan. 
Dengan aplikasi ini diharapkan menjadi lebih menarik dalam pembelajaran mengenai networking operating system. Luaran dari penelitian ini adalah sebuah Networking Operating System (NOS) berbasis simulasi multimedia.

Sistem operasi secara garis besar dibagi menjadi 2 yaitu open source dan close source. Istilah open source dalam arti kode dari program diberikan pengembang untuk dapat diakses dan dipelajari oleh masyarakat umum. Untuk kemudian hari dapat diedit atau dikembangkan serta disebarluaskan. Jika seorang pengembang melarang orang lain untuk menyebarluaskan, artinya sistem operasi tersebut tidak lagi open source melainkan close source.

Berbeda dengan sifat sistem operasi yang close source. Sistem operasi ini sangat tertutup, sehingga orang lain tidak dapat mengembangkan sistem operasi ini. Jika pengguna/masyarakat umum ingin mengembangkan sistem operasi ini harus menghubungi pengembang sistem operasi yang bersifat open source. Beberapa sistem operasi yang bersifat open source antara lain sistem operasi windows [2].

Sistem operasi jaringan merupakan sebuah sistem operasi yang dapat membantu masalah jaringan. Pada teorinya sistem operasi jaringan ini dibagi menjadi berbagai layanan/service yang berfungsi untuk melayani user. Seperti pada Gambar 1 memperlihatkan gambaran dari sistem operasi jaringan. Layanan tersebut antara lain berbagi berkas, pelayanan untuk penggunaan printer yang dipakai secara bersama, servis DNS, servis http, serta layanan lainnya. Istilah sistem operasi jaringan ini mulai dikenal pada dekade tahun 1980 sampai 1990 [3].

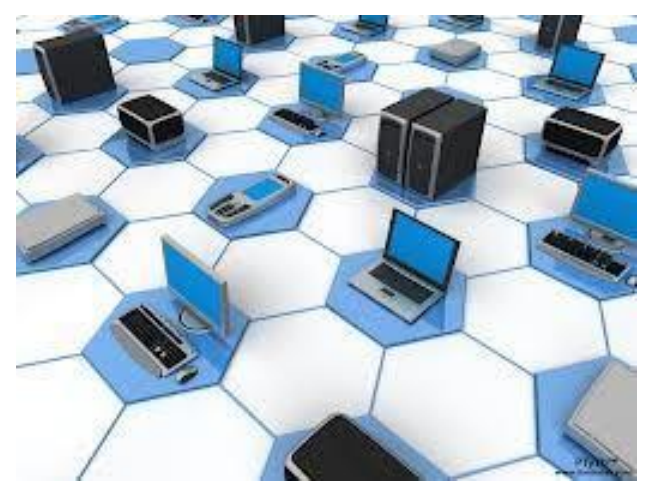

Gambar 1. Sistem Operasi Jaringan

Macam-macam sistem operasi jaringan antara lain sebagai berikut:

a. Microsoft LAN Manager

Microsoft Corporation bersama-sama dengan 3Com Corporation mengembangkan sistem operasi jaringan. Pengaturan LAN dirancang untuk mengembangkan perangkat lunak server jaringan yang dijalankan pada sistem operasi MS-DOS.

LAN Manager versi akhir yaitu versi 2.2 diimplementasikan ke dalam OS/2 1.31 menjadi sistem operasi server Microsoft. Versi ini sebelum digantikan oleh Windows NT Server pada tahun 1994 [4].

b. Novell NetWare

Novell netware merupakan sistem operasi jaringan yang diimplementasikan pada Komputer IBM. Pengembang dari novell netware bernama Novell. Sistem operasi ini dibuat berbasiskan berdasarkan tumpukan protokol jaringan Xerox XNS.

c. Microsoft Windows NT Server

Sistem Operasi Windows NT diciptakan dengan beberapa edisi yang berbeda. Produk ini dibangun berdasar kesamaan kode sumber, antara lain windows NT workstation yang diciptakan khusus untuk computer workstation jaringan.

d. Banyan VINES

Banyan VINES (singkatan dari Virtual Integrated Network Service) merupakan sistem operasi jaringan tren pada tahun 1980 sampai 1990. Pengguna sistem operasi jaringan ini diimplementasikan banyak di perusahaan-perusahaan.

Penelitian terkait pertama diangkat oleh peneliti bernama Satriedi. Dalam jurnalnya Eksploitasi RPC yang diterapkan pada sistem operasi windows bahwa beberapa kelemahan sistem operasi RPC yang digunakan oleh para hacker/cracker. RPC merupakan protokol dengan mekanisme komunikasi suatu proses. Di mana hal ini mengijinkan program yang berjalan pada komputer tanpa eksekusi kode pada sistem jarak jauh. Namun kelemanhan ini dimanfaatkan oleh hacker/cracker untuk mengeksekusi kode dengan wewenang administrator sistem local yang terinfeksi [5]. 
Melalui penelitian kedua yang diungkapkan oleh muslim pada jurnalnya, menjelaskan tentang penggunaan sistem operasi linux yang dapat digunakan untuk game. Dari beberapa distro seperti linux mint, klikit, kubuntu dan lain sebagainya yang digunakan untuk kebutuhan umum. Sementara terdapat salah satu distro linux yang dikhususkan untuk aplikasi game. Kebutuhan inilah yang menyebabkan pengguna migrasi dari sistem operasi windows ke linux. Tujuan penelitian ini adalah membuat distro baru linux yang dapat mendukung permainan, baik game yang berbasis linux maupun windows. Dengan tujuan ini diharapkan pengguna game yang terbiasa memainkan game berbasis windows tidak khawatir untuk memainkan game di platform linux. Distro baru sistem operasi ini memiliki nama "Semutireng 1.0" yang berbasis Ubuntu. Sistem operasi tersebut diolah menggunakan bantuan aplikasi remastersys distro Ubuntu [6].

Penelitian terkait ketiga mengambil dari seminar nasional yang diteliti seorang mahasiswa yaitu Abdul Khafid. Dalam penelitiannya menjelaskan tentang sebuah kegiatan manasik haji yang dikemas ke dalam multimedia. Sehingga dalam penelitian ini mengubah media pembelajaran manasik haji yang sebelumnya beruba teks menjadi berbasis multimedia. Dengan adanya manasik haji berbasis multimedia ini menjadikan materi, do'a dan simulasi untuk rukun haji menjadi lebih interaktif dan menarik [7].

\section{METODOLOGI PENELITIAN}

Dalam membangun penelitian ini menggunakan metode prototype. Dalam metode ini memiliki beberapa tahapan yaitu pengumpulan kebutuhan dan perbaikan, desain, bentuk prototype, evaluasi pelanggan, perbaikan dan produk rekayasa, seperti yang tergambar pada Gambar 2. Metode ini berfungsi untuk mengetahui kemampuan sistem operasi dan tampilan antar muka yang menghubungkan manusia dengan Komputer [8].

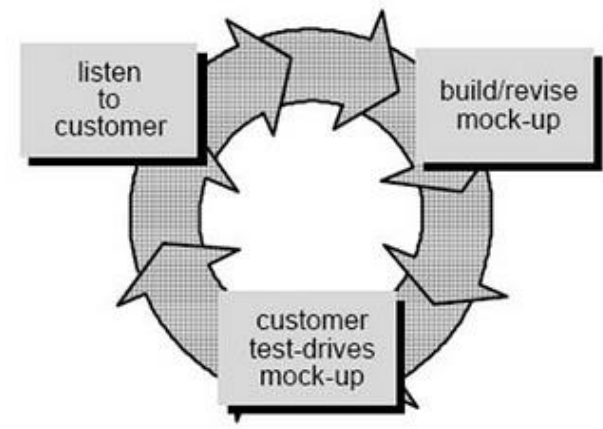

Gambar 2. Model Penelitian Prototype

Tahapan Metodologi Prototipe:

a. Pengumpulan Kebutuhan dan perbaikan

Pada tahapan ini penelitian mengumpulkan kebutuhan untuk menyusun networking operating sistem berbasis multimedia ini. Tahapan ini terdiri dari observasi dan wawancara.

1. Observasi

Dalam observasi hal yang dilakukan adalah melakukan pengamatan untuk pengumpulan data. Kegiatan observasi dilakukan dengan mengikuti penjelasan sistem operasi jaringan yang dilakukan di Unviersitas Muria Kudus.

2. Wawancara

Untuk mendapatkan data dalam penelitian ini dilakukan wawancara terhadap nara sumber yang berkompetensi di bidang ini.

b. Desain

Tahapan desain merupakan langkah setelah pengumpulan data. Dalam penelitian ini menggunakan perancangan menggunakan flowchart.

c. Bentuk Prototipe

Langkah setelah perancangan yaitu menterjemahkan perancangan ke Bahasa pemrograman.

Dalam hal ini menggunakan content management system.

d. Evaluasi Pelanggan Terhadap Prototipe

Pada tahapan evaluasi penelitian ini diterapkan untuk pengguna aplikasi ini melalui website.

e. Perbaikan Prototype

Dari proses evaluasi terdapat masukan untuk penyempurnaan aplikasi ini. Tahapan ini dilakukan pada tahap perbaikan prototype yang kemudian ditindaklanjuti untuk perbaikannya.

f. Produk Rekayasa

Aplikasi yang telah melewati berbagai tahapan ini menjadikan aplikasi menjadi lebih baik dan siap untuk didistribusikan. 


\section{HASIL DAN PEMBAHASAN}

Hasil dari penelitian yang berjudul Networking Operating System (NOS) berbasis simulasi multimedia menghasilkan sebuah aplikasi android. Di mana aplikasi android tersebut dapat diunduh pada sebuah media uploader. Aplikasi ini di beri nama Netossystem yang berarti Networking Operating System.

Langkah awal yang dilakukan adalah melakukan instalasi file apk Netossystem terlebih dahulu. Pada gambar 3 merupakan tampilan icon dari aplikasi Netossystem.

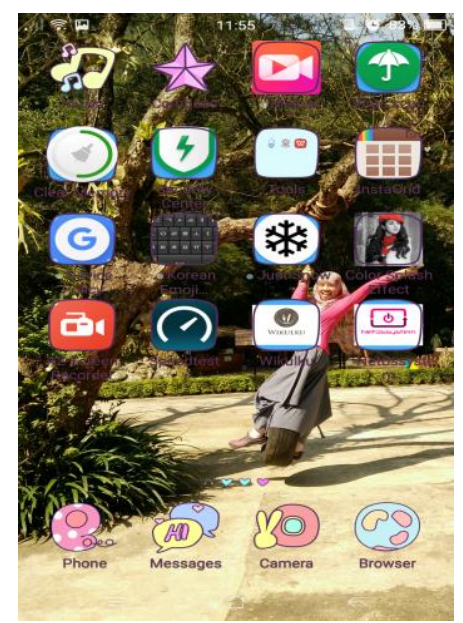

Gambar 3. Aplikasi Netossystem Di HP Dengan Platform Android

Setelah file apk sudah didapat, langkah selanjutnya ada melakukan instalasi seperti pada Gambar 4.

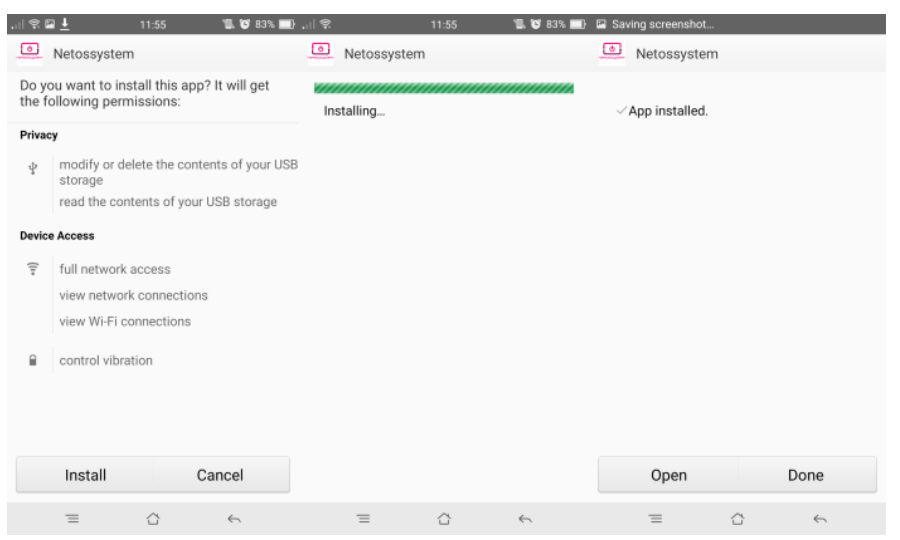

Gambar 4. Proses Instalasi Netossystem

Aplikasi Netossystem dapat digunakan sebagai mana aplikasi pada android umumnya. Pada aplikasi Netossystem ini, dapat mencari info tentang masakan daerah/khas kota Kudus. Pada Gambar 5 merupakan tampilan awal dari aplikasi Netossystem yang berisi logo dari Netossystem.

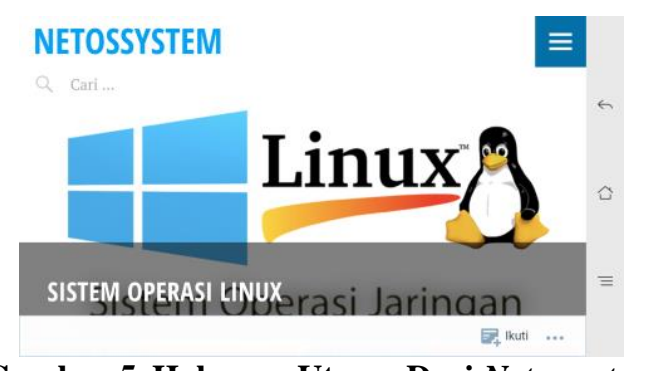

\section{Gambar 5. Halaman Utama Dari Netossystem}

Pada menu berisi tentang media sosial Netossystem, yang terdiri dari search, materi, video tutorial, home, tentang, kontak. Menu tersebut dapat dilihat pada Gambar 6. 


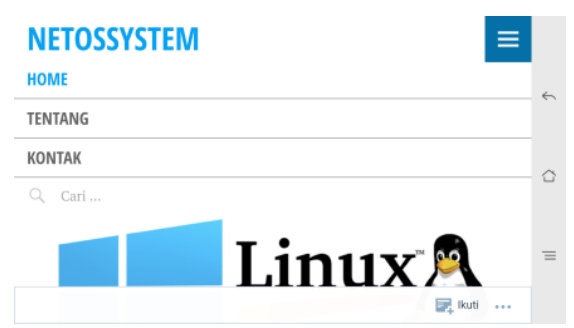

Gambar 6. Isi dari Menu Netossystem

Pada Gambar 7 merupakan materi dari aplikasi Netossystem yang dapat di lihat pada aplikasi Netossystem.

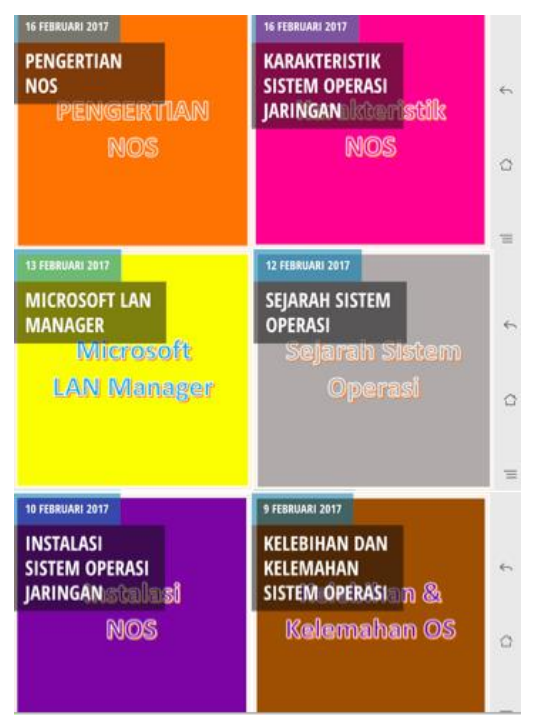

Gambar 7. Materi Pada Netossystem

Aplikasi Netossystem dilengkapi dengan video tutorial tentang instalasi sistem operasi dan sistem operasi jaringan. Video tutorial ini dapat ditambah atau dihapus oleh admin. Video tutorial dapat dilihat seperti pada Gambar 8 dan 9.

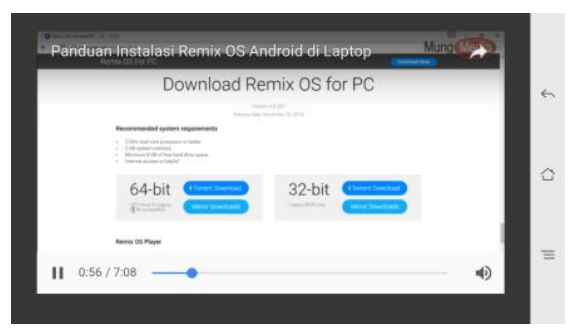

Gambar 8. Video Tutorial Netossystem

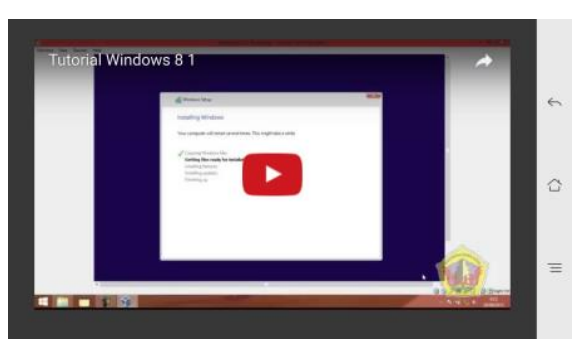

Gambar 9. Video Tutorial Netossystem

Gambar 10 dan 11 menunjukkan detail dari salah satu materi yang ada pada aplikasi Netossystem. 


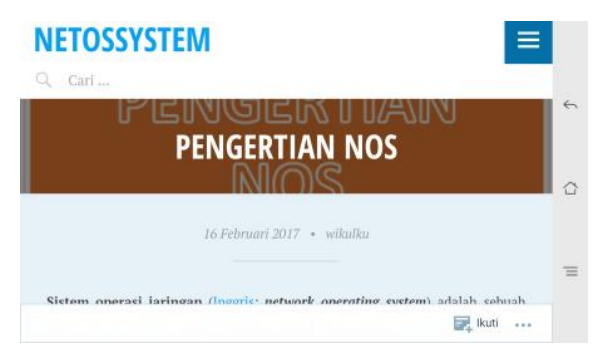

\section{Gambar 10. Detail Dari Materi Netossystem}

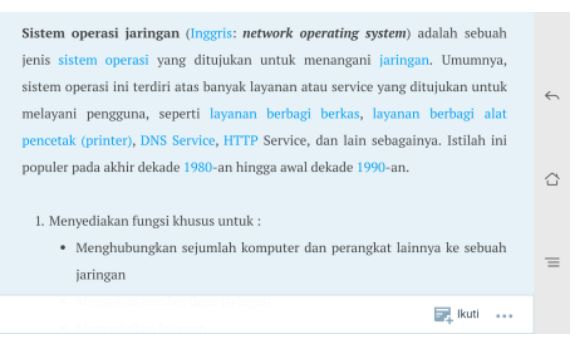

Gambar 11. Detail Materi Dari Netossystem

Pada menu aplikasi Netossystem terdapat menu tentang, yang berisi informasi tentang pembuat dari aplikasi ini. Menu tentang dapat dilihat pada Gamber 12.

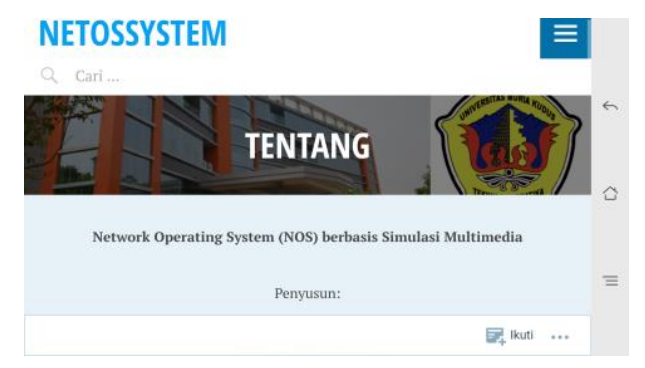

\section{Gambar 12. Menu Tentang Netossystem}

Pada menu aplikasi Netossystem terdapat menu kontak, yang berisi tempat di mana pengunjung dapat bertanya kepada admin mengenai aplikasi atau saran dari aplikasi ini. Menu kontak dapat dilihat pada Gamber 13.

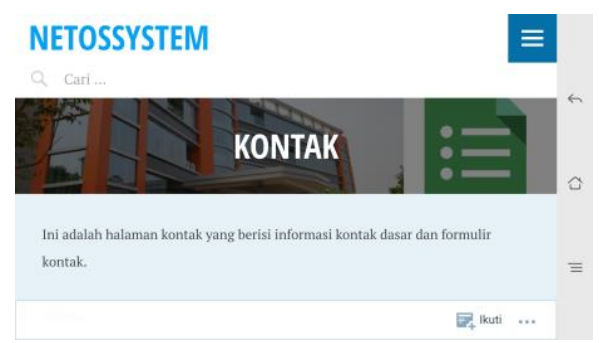

\section{Gambar 13. Menu Kontak Netossystem}

Pada Gambar 14 merupakan konfirmasi apabila user ingin keluar dari aplikasi Netossystem.

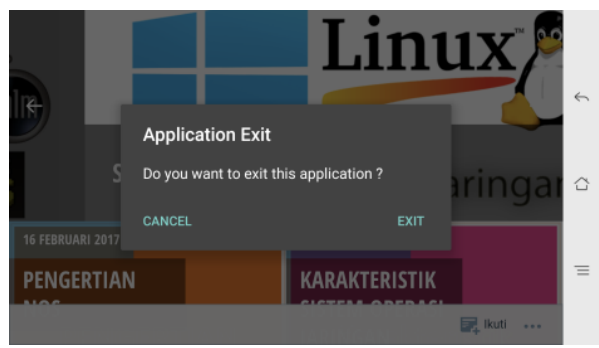

Gambar 14. Konfirmasi Keluar Dari Netossystem 
Tahapan pengujian dilakukan untuk mengetahui kualitas dari aplikasi ini. Dalam pengujian ini menggunakan pengujian beta, yaitu dengan melakukan penelitian terhadap responden/pengguna aplikasi. Hal ini dilakukan untuk melakukan pengumpulan data dengan kuesioner

Sebelum melakukan pengujian aplikasi dibagikan ke media uploader, seperti google drive dan 4shared. Hal ini dilakukan untuk sharing melalui media maya. Pada Gambar 15 dan 16 merupakan penyebaran melalui website uploader 4shared.com. Link yang dapat diakses oleh masyarakat untuk mendapatkan aplikasi wikulku adalah: http://www.4shared.com/mobile/P2nWu2xNce/Netossystem.html

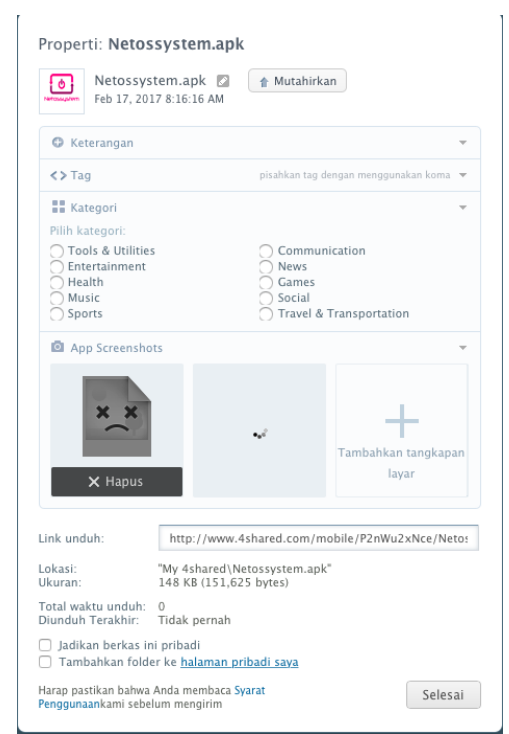

Gambar 15. Penyebaran Melalui 4shared.com

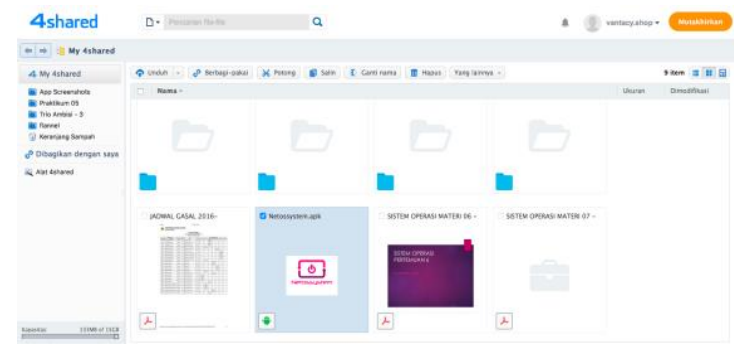

Gambar 16. Halaman 4shared.com

Pada Gambar 17 merupakan salah satu penyebaran aplikasi wikulku dengan media google drive. Dengan di upload pada google drive, masyarakat dapat mencoba aplikasi pada link sebagai berikut.

https://drive.google.com/a/umk.ac.id/file/d/0B4V7qmk8nQ_9Z0xFamZveWJYNTA/view?usp=sharing

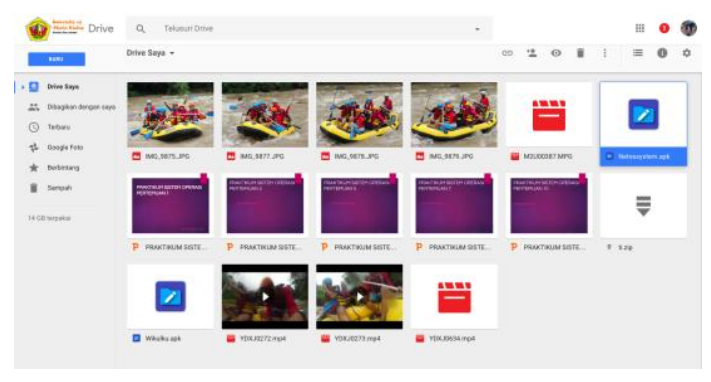

Gambar 17. Penyebaran Melalui Google Drive

Pengujian dilakukan dengan melihat statistik dari aplikasi, diantaranya rating per hari, posting makanan yang paling populer, jumlah liker. Pada Gambar 18 merupakan statistik posting materi dari Netossystem yang paling populer diakses yang diambil per 30 November 2017. 


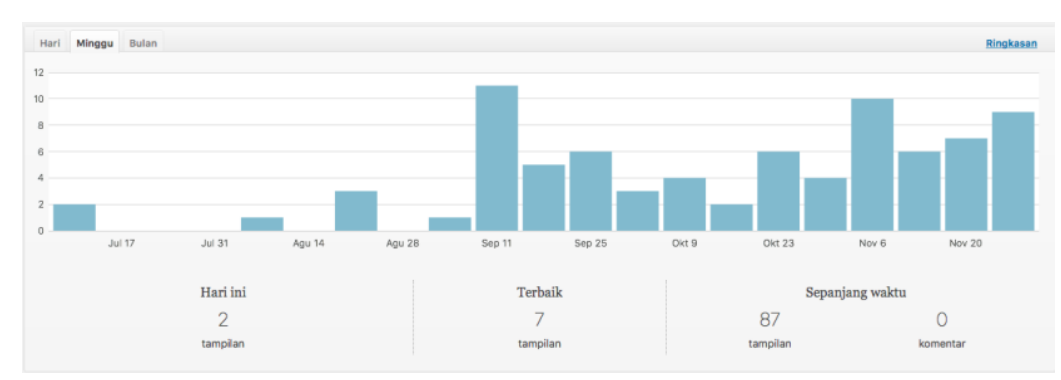

Gambar 18. Jumlah Ringkasan Aplikasi Per Hari

\section{KESIMPULAN}

Dari pembahasan penelitian yang telah diuraikan, maka peneliti dapat menarik beberapa kesimpulan, antara lain:

a. Aplikasi Netossystem dapat digunakan menggunakan smartphone yang berbasis android.

b. Aplikasi Netossystem ini juga bisa diakses melalui website https://Netossystem.wordpress.com

c. Aplikasi ini dilengkapi dengan fasilitas video tutorial yang dapat ditambah dan dihapus.

d. Aplikasi ini telah menggunakan teknologi responsive, jadi lebih fleksibel untuk tampilan menyesuaikan smartphone masing-masing.

\section{UCAPAN TERIMA KASIH}

Terima kasih kepada Lembaga Penelitian Universitas Muria Kudus, yang telah memberikan support dalam pendanaan penelitian ini sehingga SKIM Penelitian Dosen Pemula ini dapat berjalan dengan lancar.

\section{DAFTAR PUSTAKA}

[1] D. Silva, "Hampir Semua Pengguna Jaringan Internet di Indonesia memakai Aplikasi Facebook," Tribun New Batam, Batam, Oktober-2016.

[2] F. Okta, Jurnal tentang sistem operasi komputer, Pertama. Jakarta: Teknik Informatika Universitas Bhayangkara, 2015.

[3] "Sistem Operasi Jaringan," Wikipedia, 2016. [Online]. Available: https://id.wikipedia.org/wiki/Sistem_operasi_jaringan. [Accessed: 14-Oct-2016].

[4] I. Artikel, "IT Artikel.," IT Artikel, 2013. [Online]. Available: http://www.itartikel.com/2013/09/sistem-operasi-jaringan-komputer.html. [Accessed: 14-Oct-2016].

[5] S. Wahyu Binabar, "EKSPLOITASI RPC PADA SISTEM OPERASI WINDOWS," J. Din. Inform., vol. 1, no. 1, pp. 6-13, 2009.

[6] M. Aziz Muslim, "Pengembangan Distro Ubuntu untuk Aplikasi Game Centre," Din. - J. Teknol. Inf., vol. 11, no. 2, 2006.

[7] A. Khafid, T. Listyorini, and R. Meimaharani, in SNATIF (Seminar Nasional Teknologi dan Informasi, Kudus, 2015, pp. 37-42.

[8] R. Pressman, Rekayasa Perangkat Lunak: pendekatan praktisi, Buku 1. Yogyakarta: Andi Offset, 2007. 